\title{
Synthesis and Crystal Structure of 1-Methoxymethyl-3,4,5-trinitropyrazole
}

\author{
Ying-Ying LI and Jun Zhang* \\ School of Chemical Engineering and Environment, Beijing Institute of Technology, Beijing, 100081, \\ China; \\ 1260245249@qq.com, zhangjun603@bit.edu.cn*
}

Keywords: synthesis, crystal structure, trinitropyrazole

Abstract. The title compound has been synthesized and its crystal has been cultivated. The crystal structure was determined by single crystal X-ray diffraction . Crystal data: $\mathrm{C}_{5} \mathrm{H}_{5} \mathrm{~N}_{5} \mathrm{O}_{7}$, trigonal system, space group $R 3, \mathrm{a}=22.881(13) \AA, \mathrm{b}=22.881(13) \AA, \mathrm{c}=9.506(4) \AA, \alpha=90^{\circ}, \beta=90^{\circ}, \gamma=120^{\circ}$, $V=4310.1(4) \AA^{3}, M r=247.14, Z=18, F(000)=2268, D c=1.714 \mathrm{~g} \cdot \mathrm{cm}^{-3}, \mu=0.161 \mathrm{~mm}^{-1}, R=0.0491$ and $w R=0.1082$ for 3339 observed reflections with $\mathrm{I}>2 \sigma(\mathrm{I})$.

\section{Introduction}

Polynitropyrazole and its derivatives are important energetic materials, which have been widely used as anion precursors of energetic ionic salts. 1-methoxymethyl-3,4,5-trinitropyrazole is a key intermediate for the synthesis of 5-substituted-3,4-dinitropyrazole derivatives. Herein, we reported the synthesis and crystal structure of compound $\mathbf{5}$ (Scheme1). This title compound was prepared from 4-chloro pyrazole 1 by nitration, amination, oxidation and nucleophilic substitution reaction. Its structure was characterized by IR, ${ }^{1} \mathrm{H}$ NMR, ${ }^{13} \mathrm{C}$ NMR, MS and X-ray diffraction.

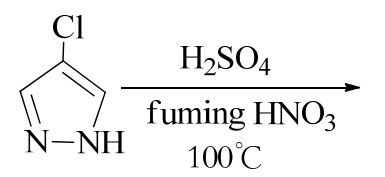

1<smiles>O=[N+]([O-])c1n[nH]c([N+](=O)[O-])c1Cl</smiles>

2

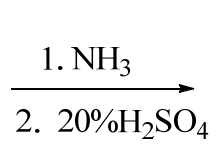

2. $20 \% \mathrm{H}_{2} \mathrm{SO}_{4}$<smiles>Nc1c([N+](=O)[O-])n[nH]c1[N+](=O)[O-]</smiles>

3

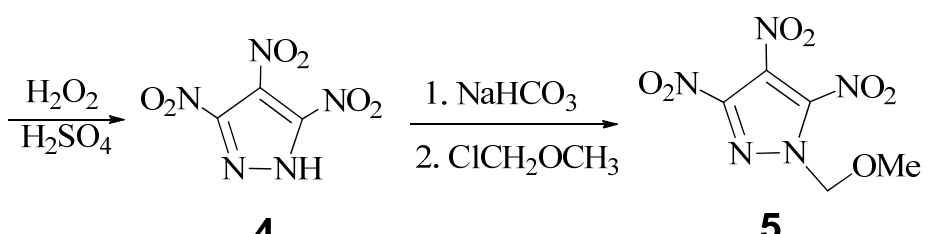

4

5

Scheme 1. Synthesis of 1-methoxymethyl-3,4,5-trinitropyrazole.

\section{Experimental}

\subsection{Apparatus and Reagents}

The melting points were measured on an XT-4B melting point apparatus(uncorrected).

${ }^{1} \mathrm{H}$ and ${ }^{13} \mathrm{C}$ NMR spectra were recorded on a Bruker $500 \mathrm{MHz}$ nuclear magnetic resonance spectrometer operating at $500 \mathrm{MHz}$ and $125 \mathrm{MHz}$, respectively. Electrospray ionization mass spectra were recorded on a Bruker Apex IV FTMS spectrometry. Infrared spectra were recorded on Bruker Alpha spectrophotometer with an ATR-Ge device. The diffraction data was collected with a Bruker SMART CCD diffractometer using a graphite monochromated MoK $\alpha$ radiation $(\lambda=0.71070 \AA)$ at $100(6) \mathrm{K}$. The starting material and all reagents were commercially available and were used without further purification.

\subsection{4-chloro-3,5-dinitropyrazol (2)}

4-chloro pyrazole $(1.537 \mathrm{~g}, 15 \mathrm{mmol})$ was added to a concentrated sulfuric acid $(18.75 \mathrm{~mL})$ at 
$0-5^{\circ} \mathrm{C}$. After complete dissolution, fuming nitric acid $(1.95 \mathrm{~mL}, 29.9 \mathrm{mmol})$ was added dropwise. The mixture was heated to $105{ }^{\circ} \mathrm{C}$, then kept for $5 \mathrm{~h}$. After cooling to room temperature, the mixture was poured into iced water, extracted with EtOAc $(100 \mathrm{~mL} \times 3)$, washed with saturated brine and dried over $\mathrm{Mg}_{2} \mathrm{SO}_{4}$. The solvent was removed under vacuum and 2 was obtained as white solid (2.48 $\mathrm{g}$, 85.8\%). M.p:156- $158^{\circ} \mathrm{C}$ (lit.: $\left.157-159^{\circ} \mathrm{C}\right)^{[1]}$.

\subsection{4-amino-3,5-dinitropyrazol (3)}

A solution of $2(1.0 \mathrm{~g}, 5.2 \mathrm{mmol})$ and $25 \%$ ammonia $(9.3 \mathrm{~mL})$ was stirred at $150^{\circ} \mathrm{C}$ in a thick-walled sealed tube for $12 \mathrm{~h}$. After cooling to room temperature, a lot of yellow crystal formed was filtered off, put into $20 \mathrm{~mL} \mathrm{H}_{2} \mathrm{O}$, and acidified with $20 \% \mathrm{H}_{2} \mathrm{SO}_{4}$ to $\mathrm{pH}=1$. Stirred for another $2 \mathrm{~h}$ at room temperature, the precipitate formed was filtered off and dried to yield $\mathbf{3}$ as yellow solid

$(0.71 \mathrm{~g}, 79.4 \%)$.

\subsection{3,4,5-trinitropyrazol (4)}

A concentrated solution of $\mathrm{H}_{2} \mathrm{SO}_{4}(23.6 \mathrm{~mL})$ was added dropwise with stirring into the solution of hydrogen peroxide $(30 \%, 11.8 \mathrm{~mL})$ at $0-5^{\circ} \mathrm{C}$. The mixture was stirred for $30 \mathrm{~min}$, and then $\mathbf{3}(1.5 \mathrm{~g}$, $8.6 \mathrm{mmol}$ ) was added in batches. After stirring at room temperature for $24 \mathrm{~h}$, the reaction mixture was poured into iced water, extracted with $\mathrm{Et}_{2} \mathrm{O}(100 \mathrm{~mL} \times 3)$, washed with saturated brine and dried over $\mathrm{Mg}_{2} \mathrm{SO}_{4}$. The solvent was removed under vacuum to provide yellow thick liquid. After standing overnight, 4 was obtained as yellow crystal $\left(1.52 \text { g, } 86.4 \% \text { ). M.p: } 185-187^{\circ} \mathrm{C} \text { (lit.: } 185^{\circ} \mathrm{C}\right)^{[2]}$.

\subsection{1-methoxymethyl-3,4,5-trinitropyrazole (5)}

Sodium bicarbonate $(1.2 \mathrm{~g}, 15 \mathrm{mmol})$ was added to a solution of 4 ( $2.03 \mathrm{~g}, 10 \mathrm{mmol})$ in $\mathrm{MeCN}(25$ $\mathrm{mL}$ ) at room temperature, the mixture was stirred for $10 \mathrm{~min}$, followed by addition of methoxymethyl chloride (1.2 g, $15 \mathrm{mmol})$. The reaction mixture was stirred for $1 \mathrm{~h}$, a precipitate was filtered off, the solvent was evaporated under vacuum, the residue was recrystallized from $\mathrm{CHCl}_{3}$ to obtain compound 5 (1.68 g, 68\%), M.p:104-106 ${ }^{\circ} \mathrm{C}$ (lit.: 104-105 $\left.{ }^{\circ} \mathrm{C}\right)^{[3]}$. IR, vmax $/ \mathrm{cm}^{-1}: 1539,1339,1247$, 1115, 889, 805, 720, 555. ${ }^{1} \mathrm{H} \mathrm{NMR}\left(500 \mathrm{MHz}, \mathrm{CDCl}_{3}\right) \delta: 3.55\left(\mathrm{~s}, 3 \mathrm{H}, \mathrm{CH}_{3}\right), 5.99\left(\mathrm{~s}, 2 \mathrm{H}, \mathrm{CH}_{2}\right) .{ }^{13} \mathrm{C}$ $\mathrm{NMR}\left(125 \mathrm{MHz}, \mathrm{CDCl}_{3}\right) \delta:$ 58.9 $\left(\mathrm{OCH}_{3}\right), 86.3\left(\mathrm{CH}_{2}\right), 123.5\left(\mathrm{C}_{4}\right), 137.4\left(\mathrm{C}_{5}\right), 143.4\left(\mathrm{C}_{3}\right) . \mathrm{ESIMS}(\mathrm{m} / \mathrm{z})$ : $202\left[\mathrm{M}-\mathrm{CH}_{2} \mathrm{OMe}\right]^{-}$.

\subsection{Crystal structure determination}

We selected the the size of $0.60 \mathrm{~mm} \times 0.55 \mathrm{~mm} \times 0.55 \mathrm{~mm}$ crystals under the microscope. The diffraction data was collected with a Bruker SMART CCD diffractometer using a graphite monochromated MoK $\alpha$ radiation $(\lambda=0.71070 \AA)$ at $100(6) \mathrm{K}$. The structures were solved by direct methods with SHELXS-97 program and refinements on $\mathrm{F}^{2}$ were performed with SHELXL-97 $7^{[4]}$ program by full-matrix least-squares techniques. Complete crystallographic data and collection parameters are listed in Table 1. The structure of title molecular and its arrangement in crystal are shown respectively in Fig 1. and Fig 2. Crystallographic data (CCDC 1409014) can be obtained free of charge from the Cambridge Crystallographic Data Centre via www.ccdc.cam.ac.uk.

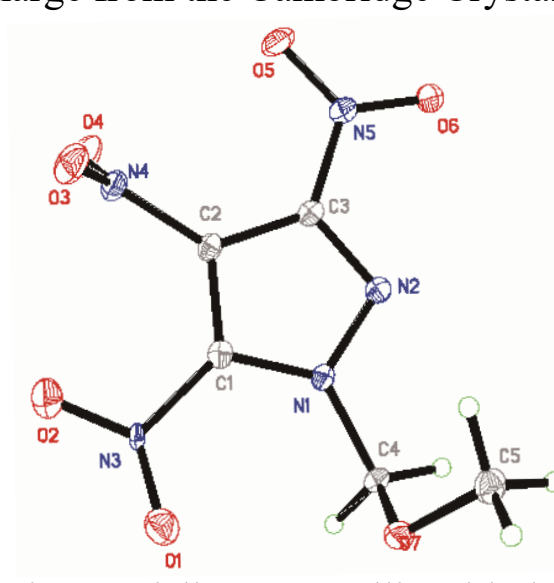

Fig. 1 Disliacement ellipsoid plot (30\%)

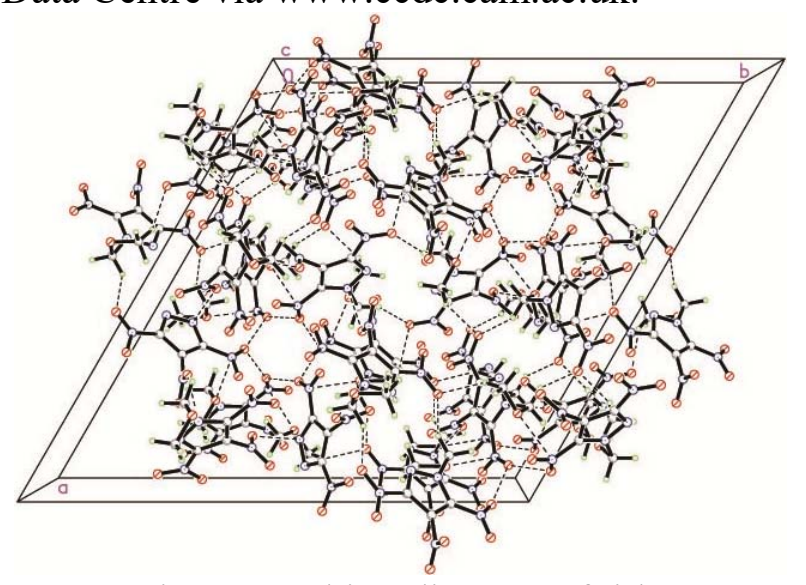

Fig. 2 Packing diagram of title compound of title compound 
Table 1. Crystallographic data and structure refinement for the title compound.

\begin{tabular}{|c|c|c|c|}
\hline Formula & $\mathrm{C}_{5} \mathrm{H}_{5} \mathrm{~N}_{5} \mathrm{O}_{7}$ & Crystal size / mm & $0.60 \times 0.55 \times 0.55$ \\
\hline Formula weight & 247.14 & $\theta$ range for data collection & 3.36 to $26.00^{\circ}$ \\
\hline Temperature / K & $100(6)$ & Limiting indices & $\begin{aligned}-28<=\mathrm{h}<=18,-13<=\mathrm{k}<=23 \\
-10<=\mathrm{l}<=11\end{aligned}$ \\
\hline Wavelength / $\AA$ & 0.71073 & Reflections collected / unique & $3339 / 1885[\mathrm{R}(\mathrm{int})=0.0255]$ \\
\hline Crystal system & trigonal & Completeness to theta $=29.14$ & $99.7 \%$ \\
\hline \multirow[t]{2}{*}{ space group } & $R 3$ & Absorption correction & None \\
\hline & $a=22.8807(13) \AA \alpha=90^{\circ}$ & & \\
\hline \multirow[t]{2}{*}{ Unit cell dimensions } & $b=22.8807(13) \AA \beta=90^{\circ}$ & Refinement method & Full-matrix least-squares on $F^{2}$ \\
\hline & $c=9.5063(4) \AA \gamma=120^{\circ}$ & & \\
\hline Volume / $\AA^{3}$ & $4310.1(4)$ & Data/restraints/parameters & $1885 / 0 / 155$ \\
\hline$Z$ & 18 & Goodness-of-fit on $F^{2}$ & 1.064 \\
\hline Calculated density $/ \mathrm{Mg} \cdot \mathrm{m}^{-3}$ & 1.714 & Final $R$ indices $[\mathrm{I}>2 \sigma(\mathrm{I})]$ & $R^{1}=0.0491, w \mathrm{R}^{2}=0.1082$ \\
\hline Absorption coefficient $/ \mathrm{mm}^{-1}$ & 0.161 & $\mathrm{R}$ indices (all data) & $R^{1}=0.0665, w \mathrm{R}^{2}=0.1181$ \\
\hline$F(000)$ & 2268 & Largest diff. peak and hole/e. $\AA^{-3}$ & 0.359 and -0.367 \\
\hline
\end{tabular}

\section{Results and discussion}

The structure of title molecular and its arrangement in crystal are shown in Fig. 1 and 2, respectively. The selected bond lengths and torsion angles are shown in Table 2 and 3.

Table 2. Selected bond lengths $(\AA)$.

\begin{tabular}{cccccc}
\hline Bond & Dist/ $\AA$ & Bond & Dist $/ \AA$ & Bond & Dist $/ \AA$ \\
\hline $\mathrm{N} 1-\mathrm{C} 1$ & $1.357(3)$ & $\mathrm{N} 4-\mathrm{C} 2$ & $1.451(3)$ & $\mathrm{N} 3-\mathrm{O} 1$ & $1.167(2)$ \\
$\mathrm{N} 2-\mathrm{C} 3$ & $1.322(3)$ & $\mathrm{N} 5-\mathrm{C} 3$ & $1.441(3)$ & $\mathrm{N} 3-\mathrm{C} 1$ & $1.478(3)$ \\
$\mathrm{N} 1-\mathrm{C} 4$ & $1.487(3)$ & $\mathrm{O} 6-\mathrm{N} 5$ & $1.222(3)$ & $\mathrm{N} 4-\mathrm{O} 4$ & $1.209(3)$ \\
\hline
\end{tabular}

Table 3. Selected torsion angles $\left(^{\circ}\right)$.

\begin{tabular}{cccccc}
\hline Angle & $\left({ }^{\circ}\right)$ & Angle & $\left({ }^{\circ}\right)$ & Angle & $\left(^{\circ}\right)$ \\
\hline $\mathrm{N} 2-\mathrm{N} 1-\mathrm{C} 1-\mathrm{C} 2$ & $0.0(2)$ & $\mathrm{C} 1-\mathrm{C} 2-\mathrm{N} 4-\mathrm{O} 3$ & $76.0(3)$ & $\mathrm{O} 5-\mathrm{N} 5-\mathrm{C} 3-\mathrm{N} 2$ & $-176.6(2)$ \\
$\mathrm{N} 1-\mathrm{N} 2-\mathrm{C} 3-\mathrm{C} 2$ & $0.2(2)$ & $\mathrm{O} 1-\mathrm{N} 3-\mathrm{C} 1-\mathrm{C} 2$ & $-171.5(2)$ & $\mathrm{O} 2-\mathrm{N} 3-\mathrm{C} 1-\mathrm{N} 1$ & $-170.6(2)$ \\
\hline
\end{tabular}

Single-crystal X-ray diffraction analysis reveals that the title molecular is composed of one pyrazole ring substituted by three nitro groups respectively in 3-, 4-, 5-position and one methoxymethyl group in 1- position of the pyrazole ring. Based on table 3, the torsion angles $\mathrm{N} 1-\mathrm{N} 2-\mathrm{C} 3-\mathrm{C} 2\left(0.2^{\circ}\right)$ and $\mathrm{N} 2-\mathrm{N} 1-\mathrm{C} 1-\mathrm{C} 2\left(0.0^{\circ}\right)$ proved that the atoms $\mathrm{N} 1, \mathrm{~N} 2, \mathrm{C} 3, \mathrm{C} 2$ and $\mathrm{C} 1$ in the pyrazole ring are almost coplane. In addition, the same result was observed that the nitro groups in 3and 5-positiond are nearly coplanar with the ring, demonstrated by the torsion angles C2-C3-N5-O6 $\left(-173.9^{\circ}\right)$ and $\mathrm{O} 1-\mathrm{N} 3-\mathrm{C} 1-\mathrm{C} 2\left(-171.5^{\circ}\right)$, respectively. On the contrary, the nitro gooup in 4-position is approximately perpendicular to pyrazole ring, shown by the torsion angle of C1-C2-N4-O3 $\left(76.0^{\circ}\right)$. The methoxymethyl group in 1- position is a twist chain streching out of pyrazole ring plane. The $\mathrm{C}-\mathrm{N}$ bond lengths in the pyrazole ring are $1.357 \AA(\mathrm{C} 1-\mathrm{N} 1)$ and $1.322 \AA(\mathrm{C} 3-\mathrm{N} 2)$, which are shorter than the normal $\mathrm{C}-\mathrm{N}$ single bond length $(1.472 \AA)$ and longer than the normal $\mathrm{C}=\mathrm{N}$ bond $(1.269 \AA)$. This fact indicates that there exists electron delocalization in the ring. Compared to $\mathrm{C} 1-\mathrm{N} 1$ bond length, C3-N2 bond length is shorter. The reason may be attributed to the fact there exist a pair of electrons in one $s p^{2}$ hybridized p-orbital of $\mathrm{N} 2$ atom, which increase electron delocalization between $\mathrm{N} 2-\mathrm{C} 3$ atoms. From Fig. 2, the weaker untypical hydrogen bond $\mathrm{C}-\mathrm{H} \ldots \mathrm{O}$ and $\pi-\pi$ stacking 
interaction between molecules were observed, which link the title molecule to form its three-dimensional crystal lattice.

\section{Conclusion}

In summary, 1-methoxymethyl-3,4,5-trinitropyrazole was prepared from 4-chloro pyrazole by nitration, amination, oxidation and nucleophilic substitution reaction according to literatuers . It was recrystallized with $\mathrm{CHCl}_{3}$ instead of $\mathrm{CCl}_{4}$ and the yield was increased. Its structure was characterized by IR, ${ }^{1} \mathrm{H}$ NMR, ${ }^{13} \mathrm{C}$ NMR, MS and X-ray diffraction. Its crystal structure was reported for the first time.

\section{References}

[1] Dalinger I L, Vatsadze I A, Shkineva T K, et al. Efficient procedure for high-yield synthesis of 4-substituted 3, 5-dinitropyrazoles using 4-chloro-3, 5-dinitropyrazole[J]. Synthesis, 2012, 44(13): 2058-2064.

[2] Wu J T, Zhang J G, Sun M, et al. Preparation, Structure and Kinetic Analysis of the Thermal Behavior of Some Energetic Salts of 3-Hydrazino-4-amino-1, 2, 4-triazole[J]. Central European Journal of Energetic Materials, 2013, 10.

[3] Dalinger I L, Vatsadze I A, Shkineva T K, et al. Nitropyrazoles 20. Synthesis and transformations of 1-methoxymethyl-3, 4, 5-trinitropyrazole[J]. Russian Chemical Bulletin, 2012, 61(2): 464-466.

[4] Sheldrick G M. SHELXTL-97, Structure determination software suite. bruker AXS, madison WI, 2008. 